\title{
La narración audiovisual como documento social e histórico: enfoques teóricos y métodos analiticos
}

\author{
Audiovisual Narratives as a Social and Historical Document: \\ theoretical approaches and analytical methods
}

\author{
Pablo Francescutti \\ Universidad Rey Juan Carlos de Madrid \\ luispablo.francescutti@urjc.es (ESPAÑA)
}

Recibido: 15.012018

Aceptado: 15.10 .2018

\section{RESUMEN}

Hace largo tiempo que las narraciones audiovisuales se han tornado un objeto legítimo de las ciencias sociales y humanas. Se las estudia como instituciones, agentes modeladores de la conciencia colectiva, práctica social o industria. En este artículo nos centraremos en su aptitud para radiografiar ciertas regiones de la experiencia socio-cultural.

La función documental de filmes y programas televisivos ha inspirado una vasta literatura más o menos sociológica, siendo mucho menor la relativa a los aspectos metodológicos de su análisis. La disparidad refleja la brecha existente entre el creciente interés por desentrañar su significado social y la escasa conciencia de las dificultades que entraña ligar los contenidos y aspectos formales de tales narraciones al contexto social, cultural e histórico. Generalizaciones abusivas, inferencias sin base y reduccionismos derivados de premisas erróneas y herramientas inadecuadas han llevado a Westwell (2007) a calificar este área de "sub-campo en busca de una metodología".

Con la intención de clarificar las carencias metodológicas referidas, en este trabajo se examinan las principales teorizaciones sobre las relaciones entre la imagen en movimiento y la realidad, seguida de una propuesta interpretativa integral de las narrativas audiovisuales, plasmada en un catálogo de las técnicas analíticas más habituales, con un repaso de sus pros y contras. Con fines demostrativos, dedicaremos la última parte a articular esos procedimientos en el diseño de abordaje de un documental televisivo de tema histórico: La Transición, de Elías de Andrés y Victoria Prego. 


\title{
PALABRAS CLAVE
}

Narrativas audiovisuales, sociología, historia, metodología, La Transición.

\begin{abstract}
Film and audiovisual narratives has long been recognized as a legitimate subject of the social and human sciences. They are studied as institutions, as shapers of collective conscience, as social practice, as an industrial goods. In this paper we focus upon their documentary value and capacity for mapping different areas of socio-cultural experience.

There is a vast body of bibliography about the social content of films and television programs, although the academic literature concerning the methodological issues related to their analysis is significantly smaller. This disparity underlines the gap between the growing interest for unraveling their social meanings and the lack of awareness of the difficulties involved in linking their contents and formal features to the social, cultural and historical context. Unwarranted generalizations, flawed inferences and reductionisms resulting from mistaken assumptions and unsuitable tools have lead Westwell (2007) to describe this field as a "sub-area in search of a methology".

In order to tackle that issue, the main theories about the relationships between the moving image and reality are discussed in the first part of this article. Next, a catalogue of the methodologies most frequently applied to audiovisual narrative is presented, accompanied by an assessment of their pros and cons. For demostration purposes, the last part is dedicated to articulate those methods in a proposal for interpreting a well-known Spanish television documentary about a highly sensitive period in Spain's history: La Transición, by Elias de Andres and Victoria Prego.
\end{abstract}

\section{KEY WORDS}

Audiovisual narratives, sociology, history, methodology, La Transición.

\section{INTRODUCCIÓN}

Legitimadas como objeto de estudio, las narraciones audiovisuales son utilizadas por sociólogos, historiadores, politólogos y filósofos como campo de pruebas de tesis e hipótesis ${ }^{1}$. Signo y sustancia de lo social, documentales,

${ }^{1}$ Para Jameson (1995) y Denzin (1991), el cine resulta fundamental para entender la lógica cultural de la postmodernidad; para Zizek (1994), es el topos privilegiado en donde desnudar la ideología actual; por no hablar de la crítica feminista a la misoginia que impregna las películas (De Lauretis, 1989). 
largometrajes de ficción, teleseries, docudramas, dibujos animados y videos caseros sirven de apoyo a generalizaciones acerca de la ideología, la cultura y la sociedad. Sin embargo, el valor académico de tales lecturas es motivo de continuas disputas. El grueso de las críticas se centra en los aspectos teóricos y metodológicos. Se acusa a muchos análisis de basarse en premisas dudosas o ni siquiera explicitadas, o de derivar de muestras poco representativas diagnósticos apresurados y atrabiliarios de toda una época o formación social (Westwell, 2007).

A pesar de las interpretaciones abusivas que únicamente documentan las filias y fobias de sus autores, dichos materiales, bien utilizados, pueden rendir un gran servicio a la imaginación sociológica. Para ello resulta crucial clarificar previamente qué se puede reclamar razonablemente al cine y a la televisión, precisar su contribución respecto de otras fuentes documentales, ponderar los instrumentos de abordaje disponibles y calibrar la proyección social de los datos obtenidos.

En este artículo haremos un repaso crítico de las principales teorías sobre la relación entre la imagen en movimiento y el mundo social. Partiendo de la influyente metáfora del cine como espejo de la sociedad, comentaremos las reflexiones de sociólogos e historiadores acerca del valor de las narraciones audiovisuales para revelar lo que la ideología y la historia oficial ocultan, y concluiremos con los hallazgos de los estudios culturales sobre la agencia mediadora de los dispositivos cinematográfico y televisivo. En congruencia con el carácter poliédrico del objeto en cuestión, defenderemos un tratamiento interdisciplinar ejemplificado en una propuesta analítica de La Transición, el documental realizado por Elías Andrés y Victoria Prego para Televisión Española.

\section{NARRATIVAS AUDIOVISUALES Y SOCIEDAD: PRINCIPALES ENFOQUES TEÓRICOS}

\subsection{Kracauer: la metáfora del espejo}

El modelo más influyente en el análisis social del cine ha sido su entendimiento como reflejo de la sociedad. Para su autor, Sigfried Kracauer (1947), "el cine es un testigo perfecto y una preciosa fuente tanto para el teórico como para el historiador" (Casetti, 1994:147), un objeto en donde la sociedad ha impreso huellas visibles, siendo, por ende, menos opaco que otras creaciones culturales.

Combinando el análisis social y el psicoanálisis, Kracauer ve en el cine expresionista alemán una ventana al inconsciente colectivo de la República de Weimar, a través de la cual se atisban los miedos de la pequeña burguesía, sus ansiedades y deseos de un líder fuerte y carismático. Partiendo del hecho del ascenso de Hitler y de la situación de la clase media alemana descrita en su obra Los asalariados (1930), buscó en la pantalla imágenes y argumentos impregnados de la ideología de aquel estamento social. En la recurrencia de ciertos moti- 
vos narrativos y estilemas visuales (el golem, el robot, el hipnotizado), detectó una voluntad de renuncia a la autonomía personal y de sumisión a una voluntad superior, el prerrequisito psicológico del fascismo.

¿En qué se sustentan las homologías entre el imaginario social y las descripciones formuladas por el cine? En la identificación del espectador, responde Kracauer. Conocedores de esta poderosa relación psicológica, los realizadores escogen y llevan a la pantalla de modo rutinario temas, imágenes y anhelos con los que el público pequeñoburgués pueda compenetrarse.

Su lecturas social de las películas tuvo enorme impacto, pero no se vio libre de críticas. Su concepción del cine como un aparato que registra la realidad sin mediaciones negaba la agencia de los creadores. Esto le impidió ver en el expresionismo la apuesta de los estudios alemanes por competir con Hollywood con una producción de calidad (Elsaesser, 2000), basada en los temas fantásticos y nostálgicos de la venerada tradición romántica que daban pie a prestigiosos experimentos formales y visuales. La misma ceguera le llevó a atribuir al conjunto de la sociedad actitudes ante la ciencia, la tecnología y el cambio social que eran privativas de realizadores deudores de esa corriente intelectual que Herf (1990) denominó modernismo reaccionario.

A soslayar la agencia de los realizadores también contribuía la perspectiva psioanalítica de Kracauer: el intérprete de un filme sería un equivalente del psicólogo que analiza las pesadillas de su paciente. Como indica Alonso (1988: 165), una cosa es plantear una analogía entre el cine y los sueños y otra muy distinta es afirmar su identidad. El psicologismo se muestra impotente ante los significados introducidos por decisiones conscientes de los cineastas y sus productoras, que ninguna lógica onírica puede explicar. Ya lo advertía Peter Burke: "Los historiadores que no tengan en cuenta la diversidad de las intenciones de los pintores o fotógrafos (por no hablar de las de sus patronos o clientes) pueden verse inducidos a cometer graves equivocaciones" (2001: 239).

Se objetó asimismo que su muestra excluía comedias, melodramas y filmes de montañismo cuyo ánimo eufórico contradecía su tesis (Rositti, 1980). Y se tachó su análisis de circular: "debe 'narrativizar' la historia alemana de un modo particular (...) donde todos los hechos conducen a Hitler y al fascismo; lo problemático es el proceso y selección de las fuerzas y determinantes que estima pertinente para nuestra comprensión de esta historia. Que deban narrativizar e incluso personalizar esas fuerzas es evidente si miramos al protagonista por él creado: el 'alma alemana', el carácter nacional,que se vuelve el juguete del instinto, el sexo, el destino, los tiranos y los demonios. La historia construida resulta así un drama expresionista, y si bien deja claro que las categorías empleadas son las que los propios filmes sugieren, no parece haber modo de escapar de su tautológico razonamiento: las películas reflejan la historia alemana, porque la historia ha sido narrada previamente en términos y categorías derivadas de las películas"(Elssaesser,1 989:24).

En cualquier caso, ninguna objeción arrebatará a Kracauer el mérito de haber asentado la valía del cine para la teoría social; lamentablemente, su legado fue 
asumido acríticamente, lastrando de modo considerable los posteriores estudios audiovisuales con pretensiones sociológicas.

\subsection{Sociólogos e historiadores frente al cine}

El sociólogo Pierre Sorlin (1977) corrige a Kracauer: el cine, más que reflejar el mundo, lo recrea con sus medios y códigos. Lejos de duplicar la sociedad, muestra lo que ésta juzga representable y, por omisión, irrepresentable. Lo visible y lo invisible trazan el contorno ideológico de cada filme.

Sorlin replantea la problemática de la representación cinematográfica. De igual modo que no todas las voces de la ciudadanía acceden a la opinión pública, no todos los colectivos sociales aparecen en la pantalla; lo prueba la escasa visibilidad de aborígenes, negros, mujeres, minorías sexuales... Por eso resulta vano exigir al cine fidelidad histórica; si de algo es fehaciente es de cómo se ve la sociedad a sí misma en un momento dado, de cómo percibe su pasado y de las estrategias técnicas y discursivas empleadas en transmitir la conciencia histórica. Para este autor, una producción de Hollywood sobre la Roma imperial habla de los Estados Unidos de los años '50 y de la visión que sus responsables tenían de la Antigüedad y de las convenciones aplicadas a plasmarla.

Sorlin defiende una metodología sintética, que aúne el estudio del relato (temas, contenidos y recursos expresivos audiovisuales) al de la institución (normas de producción, criterios estéticos, códigos comunicativos...), ya que es a través de ésta cómo se escenifica la realidad circundante.

En línea similar, el historiador Marc Ferro (1977) discierne en el cine un "contra-análisis" de cómo la sociedad quiere verse, un mentís de la "historia oficial". Tomando las películas como síntomas de temáticas reprimidas, pone el foco en las zonas no visibles: autocensuras y lapsus ideológicos. Repara así que, en la Gran Guerra, las actualidades cinematográficas nunca muestran cadáveres: la prueba indubitable de un tabú visual. Otro tanto ocurre con el silencio del cine francés sobre el conflicto de Argelia, el indicio seguro de un trauma político. Exponiendo las lagunas historiográficas, el cine funge de "revelador social"; confirma lo que el historiador sabe y le da algo que éste ignora. Los noticieros de la Rusia de 1917, por ejemplo, le informan del protagonismo de las clases medias en la caída del zarismo, un dato silenciado por la historiografía comunista.

Ferro amplía el rango de fuente documental a la ficción. Afirma que las obras ambientadas en su contemporaneidad son testigo de su presente. Sus imágenes - en particular las grabadas en exteriores, más difíciles de manipular- ofrecen un testimonio de cómo era la vida cotidiana en la ciudad y el campo en el momento del rodajo, una faceta soslayada por la historiografía tradicional.

Su método parte del contenido aparente, prosigue con las imágenes y el guion, continúa con el contexto de la producción hasta alcanzar el contenido latente, lo que no se capta a primera vista, y por fin llega a la zona no visible. No disecciona la película entera, le basta con el fragmento del lapsus o laguna. De ser posible, estudiará el material no editado: las imágenes eliminadas dicen más 
que las exhibidas. Y advierte: la incompletud congénita del cine exige cotejarlo con otros registros (solo sabremos que los noticieros de la BBC bajo el gobierno laborista omitieron el célebre discurso de Churchill sobre la Cortina de Hierro si los compararamos con sus homólogos americanos).

Su colega el estadounidense Robert Rosenstone (1997) alerta contra la creencia en que el documental da acceso directo al hecho histórico: nunca vemos los hechos sino las imágenes de ellos que los editores han querido mostrarnos. Los dramas de época, por su parte, al revivir el pasado con patetismo, apuestan más por la memoria y la nostalgia que por el rigor fáctico, reproduciendo algunos eventos con fidelidad, condensando varios en uno, o inventándoselos por necesidades dramáticas, todo al servicio de un relato cerrado, simple y completo, con énfasis en el individuo y conforme a la idea de progreso. La lectura del filme, concluye, no puede ignorar esas convenciones.

"El arte puede ofrecer testimonio de algunos aspectos de la realidad social que los textos pasan por alto", reflexiona Burke (2001:37), pero "a menudo, más que reflejar la realidad social, la distorsiona". Y añade: "el cine no da acceso al mundo social sino a las visiones propias de esa época" (ídem, pag. 239). Por eso, el análisis nunca debe olvidar que, cuanto más se interne en el pasado una recreación fílmica, más incurrirá en anacronismos en perjuicio de la fidelidad histórica.

\subsection{Estudios culturales: la lucha colectiva por los significados}

En los enfoques examinados en el apartado anterior el tropo del espejo no desaparece, deviene metáfora del espejo deformante. Al cuestionar el nexo directo entre lo real y su representación, ésta capta mejor la dialéctica visibilidad/invisibilidad, pero sigue teniendo dificultades para aprehender los sentidos introducidos por instituciones a las que adjudica una naturaleza eminentemente pasiva.

La agencia cinematográfica y televisiva sí es reconocida por los estudios culturales. Sostienen sus autores que prácticas sociales como el cine y la televisión no pueden "reflejar" simplemente la cultura pues forman parte activa de ella. La cultura es un campo de disputas donde se inventan y refuerzan significados, identidades y valores, con el resultado de que en las narraciones audiovisuales se plasman ideologías hegemónicas, disidentes y negociadas (Hall, 2010).

El cine no refleja,"transcodifica", manifiesta Kellner (2009): sus códigos narrativos y visuales trasponen los conflictos y las líneas de fuerza ideológicas de cada coyuntura en mensajes que toca "decodificar". Los cineastas, lejos de ser meros títeres de las productoras, intervienen como una "instancia del discurso" más o menos autónoma en una arena disputada. Es así que los realizadores afroamericanos replican con el Blaxploitation ${ }^{2}$ a los estereotipos racistas del mismísi-

${ }^{2}$ Dicho género, nacido en EE UU en los años '70, apela a la audiencia afroamericana urbana, ávida de tramas dirigidas y protagonizadas por actores y comunidades de su etnia, confinados por Hollywood a roles subalternos 
mo Hollywood; y es así como los filmes conservadores incorporan ingredientes contestarios como el rechazo a las grandes corporaciones para sintonizar con el malestar de las audiencias. De esas interacciones y ajustes dimana el suplemento imaginario gracias al cual —Adorno dixit - el arte trasciende el mimetismo incorporando las visiones y posturas de la comunidad de productores.

Incluir dicha agencia en el análisis redunda en una comprensión más sutil de las películas. Tomemos la explicación de Turner (1988) sobre la génesis del "nuevo cine australiano". Su perspectiva muestra cómo la creación de entes estatales de promoción del cine autóctono de "calidad" favoreció el patrocinio de estilizadas películas ambientadas en el pasado local, inspiradas en los dramas de la BBC y con aspiración de ser emblemáticas de la cultura nacional. La preferencia por el drama histórico buscaba afirmar que "Australia tenía una historia y por tanto una cultura" (Turner 1988:144). En tanto el cine comercial imitaba el entretenimiento made in USA, los filmes de época cultivaban una mirada conservadora, nacionalista, racista y exegética de la herencia europea. El investigador atento a esas entretelas se percatará que el país "reflejado" en ellos tenía más que ver con los deseos de las élites que con la Australia real, heterogénea y multiétnica.

\subsection{Televisión y realidad histórica}

Lo expuesto es válido para las narraciones televisivas, con la salvedad de que éstas se han visto más sujetas al control político del Estado y a las presiones de los anunciantes en favor de su ajuste a los mínimos denominadores comunes del gusto social.

El control ideológico se siente intensamente en los noticieros. La cobertura de las huelgas por la BBC le confirmó al Glasgow University Media Group (1976) su sesgo antisindical y pro-patronal, patente en la colocación de la cámara detrás de la policía evitando el punto de vista de los huelguistas, desmontando así la pretensión de neutralidad y objetividad de la cadena pública. No obstante, y pese a las manipulaciones de los editores, la facultad testimonial de noticieros y reportajes, acentuada por la imprevisibilidad de la conexión en directo, permite que en sus imágenes se cuelen atisbos de una realidad "en bruto" que el investigador debe aprender a detectar.

Las restricciones tampoco han impedido a las comedias de situación recrear las metamorfosis en la estructura familiar. En Bewitched/Hechizada, los poderes mágicos de Samantha simbolizan una agencia eficaz a condición de mantenerse oculta, atestiguando los límites del empoderamiento femenino en los Estados Unidos de los años '50 (Spigel, 1991). A su vez, la telenovela brasileña, tributaria del conservadurismo de la "novela rosa", se abrió a la política y las preocupaciones sociales tras la llegada de una camada de guionistas cultos y progresistas a cadenas ávidas de tramas innovadoras (Castilho Costa, 2000). Como apuntó André Bazin, que en la vida real las secretarias no se casen con el hijo del jefe millonario no reduce la enjundia sociológica de obras que reviven la leyenda de 
Cenicienta. Los formatos escapistas constituyen una fuente de primera categoría para quien estudia la continuidad y el cambio en las relaciones de clase, género o étnicas.

En cuanto a los programas de temática histórica, se observa que los elaborados con material de archivo procedente sobre todo de fuentes oficiales se decantan por narraciones lineales centradas en el acontecimiento, protagonizadas por héroes y villanos de una sola pieza y relatadas por un narrador omnisciente, para entregar una interpretación chauvinista del pasado que no deja lugar a versiones alternativas (Bell \& Gray, 2007: 130). De la pauta se apartan excepciones como la serie británica The World at War/El mundo en guerra (1973), pionera en poner la historia oral de personas corrientes al servicio de una evocación "desde abajo" de la Segunda Guerra Mundial (Chapman, 2011).

Por su parte, los docudramas estadounidenses de reconstrucción histórica segmentan la historia patria en episodios conformes a una cronología conocida por el espectador, con eje en hechos, personalidades, temas y desenlaces familiares. No ofrecen sorpresas, resume Cohn (1976); evitando las controversias que enfrentan a los historiadores, tales programas suministran visiones consensuales y unitarias de una historia nacional exitosa, adobadas de piedad, nostalgia e inocencia.

\subsection{Consideraciones teóricas finales}

Si en algo coinciden los enfoques comentados es en considerar a todos los géneros o formatos audiovisuales como documentos sociales. A la mirada sociológica no le escandaliza su "infidelidad" a la verdad histórica; al contrario, ésta le incita a explorar los mecanismos detrás de las distorsiones.

Los realizadores no se limitan a pasear espejos por la historia y la sociedad; sus creaciones vienen impregnadas de una cosmovisión y, en ocasiones, de la intención expresa de influir en el público con sus imaginarios; y esto rige incluso para la televisión (recuérdese el alegato antibelicista de The Day After/El día después (N. Meyer, 1983), pese a que en este medio la agencia autorial sufre más constricciones que en el cine . Para sacar sus proyectos adelante, los cineastas se traban en pugnas institucionales en las que se deciden qué asuntos y qué colectivos serán representados y de qué manera. Quien sepa ponderar esas dinámicas no confundirá el cambio en los modos de representación con mutaciones correlativas en la realidad referida, y sabrá identificar en los relatos resultantes huellas de prácticas, mentalidades colectivas y representaciones sociales marginadas o de difícil acceso.

La dialéctica visibilidad/invisibilidad hace de la narración audiovisual un sensible marcador del cambio sociocultural e histórico, un "sistema cargado de sentido e identificador de problemas y soluciones destinado a entrar en congruencia con un gran público"(Chalvon-Demersay, 1996: 81). Ahora bien, conviene tener presente que al análisis no le incumbe "descubrir" el significado definitivo de una obra (una misión imposible debido a la polisemia del mensaje 
artístico) sino elaborar interpretaciones razonadas de la misma que faciliten una mejor comprensión de un fenómeno social lacionado. Las relaciones causales que se establezcan entre la sociedad y las obras serán, como en cualquier estudio cultural, plausibles pero difícilmente demostrables.

Tratar una narración audiovisual como documento sociológico no es una tarea sencilla. Cada obra o grupo de obras demanda un conocimiento razonable de su medio cultural y su contexto histórico, así como de sus códigos de representación. Al igual que se hace imposible entender la pintura barroca sin un dominio de la mitología clásica, la iconología cristiana y la Contrarreforma, sería temerario inferir el feudalismo japonés a partir de las películas de Kurosawa sin más. La complejidad de nuestro objeto de estudio, a caballo de la cultura, el arte, la economía y la política, impone obligadamente un tratamiento interdisciplinar (Westwell, 2007; Treacey, 2000).

Decíamos que la metáfora del espejo y el reduccionismo psicoanalítico han lastrado la aproximación sociológica a las obras audiovisuales; a esas cortapisas hay que añadir el uso abusivo de la exégesis literaria. Encarar las películas como si fueran novelas acota su estudio al argumento en detrimento de la riqueza semántica de sus dimensiones visual y sonora ${ }^{3}$. Se hace preciso un replanteamiento de los métodos textuales que parta de considerar las narraciones audiovisuales como un discurso semióticamente heterogéneo de signos lingüísticos y no lingüísticos: enunciados verbales, imágenes y sonidos (González Requena, 1985:23). Resulta indispensable, por lo tanto, una apertura a los recursos analíticos de la semiótica, la historiografía del arte y los Films Studies.

Esos métodos se combinarán con enfoques que iluminen la inserción del objeto de estudio en el contexto. Por este último entendemos tanto la intertextualidad (el conjunto de textos con los que la obra elegida dialoga) como los factores que influyen en su producción material: las industrias audiovisuales, el Estado y sus agencias, los anunciantes, las empresas de audimetría, los grupos de presión y, en última instancia, la cultura y la sociedad. Las herramientas de la sociología, la politología, la historia y la antropología dotarán al análisis de un poder explicativo superior.

De lo expuesto se sigue que el abordaje integral de filmes y programas televisivos requiere una metodología pluridisciplinar como la que se detalla en el siguiente apartado:

${ }^{3}$ Una justificada excepción es el análisis de contenido de guiones de teleseries efectuado por Sabine Chalvon-Demersay (1994). De las más de mil sinopsis enviadas a un concurso de la televisión francesa, obtuvo el fresco de un mundo sin reglas marcado por la desconfianza en los expertos, el pesimismo radical, la preferencia por los lazos electivos frente a los de adscripción familiar y local, y por la abdicación de las instituciones de su responsabilidad. 


\section{PROCEDIMIENTOS ANALÍTICOS}

\subsection{Formación del corpus:}

Advierten Serrano Pascual y Zurdo (2012: 231ss) que un paso preliminar en el diseño metodológico de una investigación con materiales audiovisuales consiste en la clarificación de las categorías analíticas pertinentes al objeto de estudio (por ejemplo: desigualdad de género, memoria histórica, ideología de los cineastas, conflictos interétnicos, militarismo, protesta estudiantil...) y de los objetivos que mediante ellas se perseguirán. A continuación, se eligirá el conjunto de narraciones más apropiado para el estudio de tales categorías.

El primer paso selectivo concierne al medio expresivo: ¿Cine o televisión? Las obras cinematográficas, menos sujetas al control uniformizante de la industria, son convenientes si nos proponemos escudriñar la agencia o ideología de un cineasta y del colectivo al que expresa. Aquí se plantea el reto de distinguir lo típico/social de lo idiosincrático/individual. Una opción es situar la obra en una corriente o género y decodificar su idiolecto estético/ideológico a la luz de las convenciones y estilemas colectivos ${ }^{4}$. Lo ejemplifica Esquenazi (2004) con su estudio de la filmografía de Jean-Luc Godard: el curso sinuoso de este exponente de la Nouvelle Vague, que de abrazarla bandera de la "americanización" acaba renegando del consumismo, Hollywood y la tecnocracia, le permite documentar el relevo generacional del campo intelectual francés. Huelga decir que estos análisis son productivos solo si se aplican al conjunto de la obra de un cineasta.

La producción televisiva, por su parte, posee el atractivo de su sintonía con los gustos y anhelos de públicos masivos; en contra, el mayor control ideológico ejercido sobre ese medio puede inducir a equívocos (la cobertura de los test nucleares por la televisión estadounidense de los años ' 50 , transmite la impresión de que la bomba $\mathrm{H}$ entusiasmaba a la población; una impresión en parte desmentida por los temores larvados que el cine de ciencia ficción de la época escenificó [Francescutti, 2004]). Quien se enfoque en dichas creaciones deberá tenerlo siempre en cuenta.

La siguiente elección concierne al género: ¿ficciones o documentales? Aunque todos los géneros son accesibles al análisis social, las ficciones resultan idóneas para el escrutinio de las relaciones sociales e interétnicas (identidades, racismo, cuestiones de género, dinámicas de grupos....). Los géneros veridictorios (documentales, reportajes, noticieros....), por su parte, han sido el vehículo de la propaganda, la historia oficial y las réplicas de los grupos subalternos, lo que les hace especialmente aptos para el estudio de la memoria histórica y las recreaciones del pasado.

${ }^{4}$ Para Esquenazi (2012), el género es el gran mediador entre la sociedad y el cine. La plasticidad de este conjunto de reglas le permite evolucionar al compás de los intereses culturales de una comunidad social determinada. El estilo de un cineasta no sería otra cosa "que su forma de apropiarse de uno o varios géneros en función de su trayectoria personal". 
El tamaño final del corpus dependerá del volumen de información que se pretenda obtener. Las series, remakes y piezas de género (western, policial, horror, thriller...) facilitan las comparaciones y la detección de fluctuaciones significativas en el plano sincrónico o diacrónico. Si el número de obras que reúnan las características deseadas obliga a trabajar con una muestra, se optará por las que garanticen una representatividad teórica (expresen las categorías teóricas básicas) o, en su defecto, por las que aporten "la máxima diversidad socio-estructural de las posiciones, de los conflictos, de las relaciones, de los lugares de emisión y recepción de las imágenes" (Serrano Pascual y Zurdo, op. cit., p. 232). Un criterio adicional lo aportan las cifras de taquilla: la afluencia de público ayuda a identificar algunas de las obras que mejor encajan con su imaginario cultural.

La disponibilidad de las obras condiciona en grano notable la formación del corspu. Por fortuna, la dependencia de archivos institucionales se ha visto reducida considerablemente gracias a la digitalización y al surgimiento de archivos informales como Youtube, que brindan acceso a ingentes cantidades de material, sobre todo cinematográfico (solo muy recientemente las cadenas televisivas adoptaron la costumbra de conservar copias de los programas emitidos). Otra tanto puede decirse de la proximidad física y cultural con el objeto de estudio. Quien desconozca la lengua, la historia y la cultura de Egipto, por poner un caso, ni disponga de recursos para trasladarse a ese país si hay que entrevistar a los realizadores o buscar en archivos, tendrá muy difícil profundizar en el significado social de una teleserie egipcia. De ahí que, con frecuencia, la pesquisa deba ceñirse a las creaciones del ámbito geográfico o cultural más accesible para el investigador.

El corpus constituido tras esas decisiones se analizará con las técnicas expuestas a continuación:

\subsection{Análisis textuales}

\subsubsection{Análisis de contenido}

Desde que fue aplicado al cine con la misión de contabilizar los contenidos violentos en el marco de los Payne Fund Studies (Jowett et al., 1996), ha cuantificado, entre otras variables, la interacción entre personajes masculinos y femeninos (Wolfenstein y Leites, 1950), el fomento del tabaquismo (Escamillo, 2000), la sub-representación y encasillamiento actancial de etnias, sexos y clases sociales, o la manipulación informativa (Aideka, 2002). Al ceñirse al contenido manifiesto, esta técnica no capta los sentidos soterrados (la ambigüedad del cine negro acerca de la justicia y el crimen, pongamos por caso), ni autoriza a inferir interpretaciones globales. Pero las limitaciones no menoscaban su capacidad 
para generar descripciones valiosas en corpus numerosos, cuyo significado explorarán otras metodologías.

\subsubsection{Análisis del relato}

En la medida en que nos las vemos con narraciones, son accesibles a las técnicas formalistas forjadas por Propp, Levi-Strauss y Greimas. Estas aconsejan discernir la situación inicial y el desenlace de la trama (Barthes, 1974). No es lo mismo un filme sobre la Revolución Francesa que comience con la toma de la Bastilla que otro que empiece con el Terror. Muchas historias suelen arrancar en un estado de desequilibrio social (la comunidad perturbada por una amenaza exterior: el tiburón en la pieza de Spielberg) que la conclusión subsana (los finales importan porque en ellos se fija el mensaje que se quiere transmitir). Ambos extremos informan de la escala de valores en liza y de los medios más convenientes para preservarlos (la formación de la pareja heterosexual en el happy end como modo imaginario de solventar contradicciones sociales).

Pasemos a las transformaciones de los personajes a lo largo del itinerario narrativo. En el esquema actancial de Greimas, los actantes son funciones narrativas que pueden repartirse en varios actores. En virtud del uso sistemático de la sinécdoque en las intrigas, un actante individual encarna una posición o colectivo social, las escenas íntimas condensan situaciones colectivas, y las acciones de un sujeto, el devenir de pueblos e instituciones (Guynn, 2006). Esto hace del modelo actancial un instrumento óptimo para trascender las rivalidades personales que motivan las tramas, insertarlas en un marco macrosocial y vincularlas a las categorías de etnia, clase, edad, estatus, género, valores...

Aplicando esas directrices a La Marsellaise/La Marsellesa (Jean Renoir, 1938), vemos que el sujeto lo componen los marselleses, el pueblo francés y los jacobinos; el objeto es la defensa de la revolución; el dador se reparte entre el cura, los patriotas y los pescaderos; los oponentes se encarnan en la monarquía, los aristócratas y los prusianos; los coadyuvantes, en el cura y la madre del marsellés Bomier; y el destinatario es la Nación. Al confundirse sujeto, coadyuvantes y objeto con la Nación, el relato se torna reflexivo, ilustrando cómo el bajo clero, el pueblo en armas y los jacobinos, defendiendo la república, se convierten en la esencia viva de la nación (Guynn, op. cit.).

Otra puerta de acceso a la "estructura profunda" de la narración son las oposiciones binarias que el estructuralismo nos enseñó a identificar. Esos patrones dicotómicos, en la medida en que estructuran campos semánticos (clase social, género....), iluminan contradicciones sociales específicas: la identidad nacional racista subyacente al choque entre blancos e indios en el western; la desconfianza en las instituciones, sustrato del conflicto entre el individuo y la sociedad en el cine de los años '70 (la rapacidad del alcalde y los empresarios del balneario frente a la conciencia del deber del jefe de policía en Jaws). Igual de reveladoras son las resoluciones propuestas: el triunfo de los viajeros frente a los apaches en 
Stagecoach/La Diligencia (Ford, EE UU, 1939); la victoria pírrica del agente honesto frente a la policía corrupta en Serpico (Lumet, EE UU, 1973).

\subsubsection{Análisis paratextual}

El paratexto - enunciados que envuelven al texto principal y preparan su recepciónentrega información adicional sobre las intenciones significativas de los realizadores (el espectador target, la adscripción genérica de la obra...). El paratexto editorial (carteles, publicidad...) actúa de modo similar a la titulación periodística, proveyendo al espectador de instrucciones de lectura en una dirección determinada; el paratexto autoral (títulos de crédito, trailers, declaraciones...) aporta pistas del sentido que el autor quiere infundir a su creación (en The Post/Los archivos del Pentágono [Spielberg, 2017], las declaraciones del director calificando a su film histórico como un alegato por el feminismo y la libertad de prensa amenazada por la administración de Donald Trump.)

\subsubsection{Análisis audiovisual}

Citaremos en primer lugar los procedimientos analíticos aquilatados por los Film Studies (Tejedor, 2014): la duración de los planos y el número de fotogramas; la escala de los planos; la profundidad de campo; la presentación de personajes y objetos en profundidad, el objetivo utilizado, ; el montaje (raccords; puntuaciones; movimientos de la cámara y de los actores en el campo) o la incidencia angular (el picado desde la noria en The Third Men/El Tercer Hombre [C. Reed, 1949], sugerente de la perspectiva de superioridad amoral del protagonista).

Otros aspectos a atender son los títulos de crédito que aportan claves genéricas (Inceer, 007); los cromatismos (el sepia del pasado nostálgico; el blanco y negro de la "objetividad" o del "rigor histórico"); la escenografía (los techos bajos que simbolizan los límites impuestos por el entorno a los personajes); los iconos (el platillo volador de la ciencia ficción, emblema de promesas y amenazas tecnocráticas); el vestuario (la moda de los años '40 en Blade Runner que reenvía al cine negro); y la naturaleza de las imágenes (documental, animación, sintéticas...).

El sonido, por su parte, ayuda a caracterizar los personajes (la música de Beethoven en A Clockwork Orange/La Naranja Mecánica [Kubrick, 1971] define la psicología del protagonista); establece analogías (la Cabalgata de las Walkirias en Apocalypse Now [Ford Coppola, 1979] asocia la intervención estadounidense en Vietnam al nazismo); fecha el escenario (la música barroca evoca los siglos XVII y XVIII); produce efectos de realidad (cañonazos y disparos son de rigor en el documental bélico); identifica el género (notas ominosas anticipan un relato de horror o suspenso); y emociona (la amenazadora Marcha Imperial en Star Wars [Lukas, 1977]). La voz over delata al narrador omnisciente (la voz del saber en el documental); mientras timbres e inflexiones vocales informan de 
la psicología y el trasfondo socio-cultural de los personajes: el acento alemán del Dr. Strangelove en Dr. Strangelove/ ¿Teléfono rojo? (Kubrick, 1964) alude al origen nazi del programa de misiles americano; el habla maquinal de los extraterrestres, a la deshumanización tecnológica.

Finalmente, se examinarán los vínculos entre sonido e imagen (posición de la fuente sonora respecto de la imagen, sincronismo o asincronismo entre ambos) para, a continuación, integrar los datos del análisis audiovisual con los de la estructura narrativa, sin perder de vista que la polisemia de la imagen (Burgin, 2004) hace de su "decodificación" una operación irremesiblemente subjetiva.

\subsection{Métodos contextuales}

\subsubsection{Análisis intertextual}

Se aplica a las citas, alusiones o parodias que remiten a la red formada por las obras con las que el corpus dialoga. Si se trata d una adaptación, es obligado prestar atención al original (el contraste entre la novela Las Uvas de la Ira de Steinbeck y la versión de John Ford nos apercibe de los cambios y omisiones introducidos para reconducir un alegato social en una épica familiar despolitizada). A través de la intertextualidad, el rastro de los motivos comunes posibilita comparaciones fecundas (en Jaws/Tiburón [Spielberg, 1975], las citas al drama de Ibsen Un enemigo del pueblo para aludir a las mezquinas autoridades del balneario transparentan la desconfianza social en las instituciones extendida en los Estados Unidos en los años '70).

\subsubsection{Análisis institucional}

Estudiosos de la industria del cine (Jarvie, 1970; Bordwell \& Thompson, 1997; Schatz, 1981) y de la televisión (Williams, 1974; Cantor \& Cantor, 1992;) son unánimes: las formas de representación son indisociables de sus modos de producción. El Estado tiende a subvencionar obras que refuercen la identidad nacional, atiendan los gustos de las capas ilustradas y eviten temas espinosos; en el cine comercial las economías de escala priman determinadas opciones estilísticas $^{5}$; y en la televisión comercial, la presión de los anunciantes privilegia las tramas y personajes acordes al público-target.

A la mirada atenta a la faz institucional de Hollywood no se le escaparán las conexiones entre las producciones bíblicas de los años '50 (Ben Hur, La tú-

\footnotetext{
5 Al estilo clásico de Hollywood (Bordwell y Thompson, 1997) lo define una narración que avanza hacia un desenlace inequívoco impulsada por motivaciones psicológicas, conforme a un tiempo lineal y uniforme, con planos centrados en la figura humana (gestos y expresiones faciales en especial) montados mediante la edición en continuidad.
} 
nica sagrada...) y el afán de los productores judíos por aplacar el antisemitismo de los años '50; ni entre la persecución judicial al pacifismo y la disminución de películas antibélicas a lo largo de la Gran Guerra (Manchel, 1990:262); ni entre la insistencia del cine policial de los años '30 en el respeto de la ley y las buenas costumbres y el temor a la acusación de inmoralidad agitada por las asociaciones religiosas.

Quien indague esa faceta se apoyará en los documentos internos de la industria, las cartas de directores y guionistas, las actas de la censura, las polémicas públicas a raíz de la política audiovisual. Las entrevistas a directores, guionistas, críticos, actores y productores - una vez contrastadas críticamente - le dirán cómo se negoció un guión, las interferencias que obligaron a modificar el planteamiento original, o las razones subyacentes a ciertas representaciones ${ }^{6}$. De exigirlo el estudio de las rutinas de producción, practicará la observación participante en los rodajes.

\subsubsection{Análisis socio-cultural}

Aprehender el contexto que se extiende más allá del perímetro de la industria audiovisual aconseja echar mano de categorías descriptivas y explicativas de la sociedad y la cultura dentro de la que se concibieron la/s obra/s ("sociedad del espectáculo", "neotelevisión", o "postmodernidad", dependiendo del período temporal escogido y las preferencias del analista).

Pertrechado con el marco categorial más conveniente para los fines de su pesquisa, el investigador recurrirá a fuentes secundarias recogidas en libros y revistas, entrevistas a expertos, protagonistas o testigos de los hechos representados, o a las estadísticas (por ejemplo, a quien investigue la representación fílmica de la clase trabajadora, las cifras de conflictividad laboral le indicarán si el pasaje del "obrero combativo" del cine político de los "70, al "obrero víctima" de la filmografía reciente se corresponde con los cambios en la realidad de las fábricas).

\subsection{Consideraciones metodológicas finales}

La diversidad de ángulos de abordaje plantea una pregunta práctica: ¿por dónde empezar, por el texto o por el contexto? La respuesta es simple: depende de lo que se busque. Si se quiere verificar una hipótesis sociológica o histórica se partirá del contexto al cual aquella se refiere y se procederá a verificarla mediante el análisis de un corpus audiovisual; si lo que se pretende en cambio, es desentrañar la significación social de una obra o corpus, se comenzará con su

${ }^{6}$ Interrogar a los realizadores sirve además para atajar suposiciones erróneas. Saber que la invisibilidad de ciertos personajes en un documental responde a la indisponiblidad de imágenes, evitará atribuirla a un designio censor. 
estudio textual para obtener los elementos cuyo trasfondo social o histórico se buscará ligándolos a su contexto.

Ejemplificaremos el último movimiento tomando como pieza de demostración la producción polaca Faraon/Faraón (J. Kawalerovicz, 1966). Su esquema actancial nos dice que versa sobre la pugna entre el faraón (sujeto) y la casta sacerdotal (oponente): un poder maligno que explota la superstición del pueblo con la intención de controlar Egipto (objeto). ¿Qué sentido tiene una épica semejante, en apariencia afin a Hollwood, en la industria cinematográfica de un Estado comunista?

La siguiente parada será en el intertexto: la novela homónima de 1895 que inspiró a Kawalerovicz. Saber que su autor, Boleslaw Prus, exponente del nacionalismo polaco, imaginó el Egipto faraónico como un trasunto de la Polonia del siglo XVIII, nos dará una clave de lectura. Su imputación al oscurantismo religioso de la decadencia egipcia, que el filme acentúa, nos proporcionará claves adicionales acerca de la analogía propuesta. El talante anticlerical de la película anterior del cineasta, Matka Joanna od Aniolów/Madre Juana de los Angeles (1961), aportará otro motivo para interpretar Faraón con un encuadre crítico de la institución eclesiástica.

Finalmente, el contexto histórico: la industria cinematográfica de la Polonia socialista, su modo de producción, sus valores y la postura de Kawalerovicz frente al régimen de Gomulka; $y$, por supuesto, la coyuntura política. No tardaremos en encontrar un paralelismo entre el argumento del filme y el conflicto del Estado con la iglesia católica, lo que fundamente su interpretación como una crítica velada al clero polaco estrenada en un momento de máxima tensión entre ambos poderes.

A la manera del círculo hermenéutico (Sánchez Meca, 2004), el análisis avanza en un vaivén del texto al contexto; un movimiento de espiral ascendente que produce lecturas integradoras de los sistemas de significaciones inasequibles a la mirada enfocada solo en lo textual o en lo contextual.

\section{PROPUESTA DE ANÁLISIS DE LA TRANSICIÓN}

\subsection{Introducción:}

La Transición, serie producida por RTVE y realizada por Elías de Andrés y Victoria Prego, recrea en formato documental la evolución política en España desde el asesinato del almirante Carrero Blanco en diciembre de 1973 hasta las elecciones democráticas de junio de 1977, pasando por la muerte de Franco, la investidura del Rey, la matanza de Atocha y la legalización de los partidos políticos. Emitida en 1995 en 13 episodios de casi una hora de duración, tuvo una audiencia de dos millones de espectadores, sin contar el público de sus reposicio- 
nes en 1996 y 2007. Su impacto se multiplicó posteriormente al ser distribuida en videocassette por el diario El País.

Dos cualidades adicionales acreditan su interés académico: por un lado, constituye el intento más ambicioso de la televisión por "historiar" el tránsito de la dictadura a la democracia, al punto de que para muchos es la versión cuasi-oficial de ese período (Alegre, 2000); por el otro, se ha vuelto el blanco de quienes impugnan los "grandes relatos" de aquellos años (Gallego, 2008).

Tales razones hacen de la serie un material susceptible de enriquecer el debate en torno al pasaje del franquismo a la democracia y el funcionamiento mediático de la memoria colectiva.

\subsection{Marco teórico}

Para conceptualizar el funcionamiento general del aparato televisivo invocaremos la categoría de industria cultural acuñada por la Escuela de Frankfurt y matizada por los estudios culturales (Hall, 2010), amén de las aportaciones de la economía política de la comunicación (Mattelart, 2006). En el plano particular acudiremos al estudio de la televisión estadounidense de Gitlin (1983) y el de Bustamante (1999) sobre la economía de su homóloga española. Los trabajos de Palacio (2009) y Conde Martín (1999) sobre la historia de TVE esclarecerán su tránsito del franquismo a la monarquía constitucional y su manejo propagandístico por los gobiernos de turno. Completaremos el andamiaje teórico con la bibliografía más relevante sobre el tratamiento televisivo de los temas históricos, incluidos los autores extranjeros citados en el apartado 2.4 junto con especialistas españoles (Hernández Corchete, 2008; Rueda Laffond y Coronado Ruiz, 2009; Paz Rebollo y Montero Díaz, 2015), además de análisis previos de La Transición de Andrés y Prego (Alegre, 2000; Hernández Corchete, 2010 y 2013).

\subsection{Objetivos}

Del programa elegido cabe esperar que documente el contexto de su producción (la televisión pública en la democracia, la España socialista....) y la visión del pasado que pretende transmitir. Este último aspecto constituye el objeto de la investigación que a continuación se propone: interpretar su relato de aquel periodo histórico para su ulterior cotejo con la historiografía. Entre sus objetivos secundarios figura el estudio de aspectos cruciales de la representación mediática del pasado: relación entre acontecimientos y procesos (toda vez que la Transición fue un proceso); régimen de historicidad implícito en la serie; recursos empleados en producir efectos de verdad; y, por último, el papel de la televisión en la construcción de una historia nacional común. 


\subsection{Metodología}

\subsubsection{Corpus:}

Los trece capítulos que componen la serie formarán el corpus de esta pesquisa que avanzará del texto hacia el contexto, en coherencia con el objetivo de interpretar primeramente el programa para luego contrastar sus rasgos formales y contenidos con su entorno histórico.

\subsubsection{Análisis textual}

\subsubsection{Caracterización genérica:}

Determinar cómo se presenta la serie al espectador (¿reportaje? ¿documental? ¿investigación periodística?....) nos revelará su filiación genérica, el contrato de lectura propuesto al público y su estrategia veridictoria (ise muestra como "una ventana a la historia”? ¿una interpretación discutible? ¿la búsqueda de una verdad oculta?). Que se trate de un documental u otro formato veredictorio deberá ponernos en guardia, dada su propensión a ser vehículo de propaganda gubernamental. Acto seguido, lo clasificaremos conforme a las seis categorías elaboradas por Nichols (1997) en función del modo de representación y aproximación a la realidad referida: expositivo; observacional; participativo; poético; performativo; o reflexivo.

\subsubsection{Análisis del relato}

Las técnicas narratológicas desnudarán su estructura argumental a partir de la definición de la situación inicial (¿dictadura en declive?) y el desenlace (¿recuperación de la democracia?) y de la identificación del objeto perseguido (¿la democracia?) y de los personajes con funciones actanciales. Previsiblemente surgirán cuestiones tales como: ¿es el héroe Adolfo Suárez y el dador el Rey? ¿O ambos ocupan la posición de sujeto al que la Nación encomienda la procura del objeto? ¿Cuál es el rol de Franco? ¿Y el del Ejército? El juego de los actantes arrojará luz sobre el rol de los altos cargos franquistas y de los líderes de la oposición, y sobre el espacio concedido a la acción colectiva de sindicatos, estudiantes o nacionalismos periféricos. De esta manera podremos determinar si el sujeto de la trama es el pueblo español o las élites que le devuelven la libertad.

Igual de importante resulta perfilar al narrador principal (¿quién cuenta la historia? ¿toma partido frente a lo relatado?) y a los narradores subsidiarios (testigos, expertos...), especialmente en su relación con la voz principal (¿coinciden? ¿polemizan?). No importa menos la identidad del narratario (¿a quién se cuenta la historia? ¿se le presume simpatizante del héroe, de los oponentes o equidis- 
tante?). Sabremos de ese modo si estas voces hablan en nombre de la Historia, a título propio o de la sociedad española, a la vez que obtendremos pistas sobre el espectador-modelo.

Cumplido ese paso señalaremos los hitos del decurso narrativo: ¿cuál es el hecho elegido para el arranque del relato? ¿cuáles son los acontecimientos decisivos? (¿el nombramiento de Suárez como jefe de gobierno? ¿la matanza de Atocha?...). A continuación, indagaremos en las causalidades establecidas entre ellos (¿El atentado a Carrero Blanco pone la puntilla al franquismo? ¿La respuesta contenida del PCE a los crímenes de Atocha es la causa de su legalización?).

Bosquejada la armazón del relato y su elenco actancial, estaremos en condicines de valorar si se ajustan a las modalidades del documental analítico -menos apegado al orden cronológico- o a los cánones dramáticos de la ficción; si se trata de un relato cerrado sin alternativas, de una historia sobre la Transición o de "LA HISTORIA" de la Transición, o de una profecía retrospectiva que niega el azar y exagera el control de los sujetos sobre los eventos; y, en definitiva, de discernir su sentido general (¿el relato optimista del progreso moral de la sociedad española?).

\subsubsection{Análisis paratextual}

Del paratexto editorial (el discurso de TVE sobre la serie) apenas subsiste el impreso en la carátula del videocassette distribuido por El País y sus textos promocionales, lo que ayudará para reconstruir la interpretación que TVE y el periódico hicieron de la serie (no es asunto menor que el diario de referencia asuma lo expresado en La Transición). Del paratexto autorial se dispone de un buen número de entrevistas a Prego con declaraciones sobre el contexto institucional, la gestación de la obra, su finalidad y su recepción; datos a tomar con precaución porque la distancia temporal puede haber modificado el recuerdo de la realizadora.

\subsubsection{Análisis audiovisual}

\subsubsection{Análisis visual}

Se aplicará primeramente a los títulos de crédito: una secuencia de imágenes y música que se repite al inicio de cada episodio. El montaje de "momentos estelares" de la Transición resume en un minuto las trece horas de la serie y sintetiza su significado global.

En un segundo movimiento se cuantificará mediante análisis de contenido las figuras icónicas que aparecen con mayor frecuencia en la serie (¿personalidades? ¿figuras del régimen y de la oposición en igual medida?). Ciertas imágenes encierran un interés especial: ¿Juan Carlos y Franco aparecen juntos o se procura mostrarlos separados? En cuanto a las multitudes, la manifestación visual de 
la acción colectiva: ¿se las muestran violentas, pacíficas, disciplinadas? Y en cuanto a los demás estamentos sociales: ¿aparecen como un conjunto indiferenciado o son desagregados en grupos de obreros, estudiantes, sacerdotes, mujeres, militares, carlistas...?

Finalmente, encararemos la gran cuestión: ¿como se sostiene visualmente el discurso veridictorio de La Transición? ¿Qué peso tiene la evidencia "objetiva" atribuida a las imágenes tácita o expresamente? La cuestión no puede desligarse de su procedencia: ¿fueron grabadas por los realizadores in situ? ¿son recreaciones? ¿es material del archivo? En caso de ser esto último: ¿proceden de documentales? ¿de películas de ficción? ¿de noticieros? ¿de material sin editar? No es lo mismo el uso auto-referencial del telediario, con TVE garantizando su verdad, que la inserción de secuencias grabadas por cineastas cuyo sentido original ha sido resemantizado por los editores.

El recurso a los archivos acentúa la dependencia del discurso de La Transición del estatuto "objetivo" y "neutro" de las imágenes "oficiales"; de ahí la necesidad de problematizarlas. En el período cubierto TVE actuaba como un aparato de propaganda que detentaba el monopolio audiovisual. ¿Cómo se posicionan los autores al respecto? ¿toman con cautela sus materiales? ¿convalidan su veracidad? ¿o lo complementan o contrastan con imágenes de archivos no estatales?

\subsubsection{Análisis del audio}

Cuestión central: ¿quiénes hablan? De escucharse una voz over en función de narrador, ¿se identifica al emisor? ¿es hombre o mujer? El sexo de la voz no es baladí puesto que la enunciación del documental ha corrido a cargo de varones. Que la "voz de la historia" sea femenina (como es el caso) evidencia grandes cambios en los modos de la persuasión televisiva.

Seguidamente relacionaremos las voces a las imágenes. ¿Hay correspondencia entre ambas o se cuelan disonancias? ¿Formulan juicios de valor acerca de lo que se muestra? ¿Se explica al espectador lo que se le muestra? ¿Dan por supuesto que éste conoce lo que se le enseña?

En cuanto a la banda sonora, estudiaremos su uso para la datación histórica. Sus tonalidades darán pistas de la postura editorial (las notas alegres asociadas a la Revolución de los Claveles traslucen una opinión favorable) y del formato escogido (una música parecida a la sintonía del telediario realzará la índole periodística y "objetiva" del programa). Prestaremos similar atención a la presencia de canciones de la época (un tema de "protesta" antifranquista puede decirnos mucho de las simpatías políticas de los realizadores y de la "enciclopedia" supuesta del espectador). 


\subsubsection{Análisis contextual}

\subsubsection{Análisis institucional:}

La bibliografía acerca de la gestión socialista de RTVE y, en particular, de la etapa bajo la dirección de Pilar Miró, nos indicará el lugar del género del documental histórico en el seno de una programación que aspiraba a emular el modelo prestigioso de la BBC. Las declaraciones de los realizadores y las entrevistas a otros profesionales activos en los años de gestación de la serie, nos informarán de las circunstancias de su producción: ¿apostó la dirección de la cadena por el programa? ¿hubo conflictos o episodios de censura? ¿satisfizo el producto final las expectativas de la casa? ¿respondía su propósito "didáctico" a la línea editorial del ente? En breve: ¿puede tomarse La Transición como la versión de la historia que el ente deseaba transmitir?

\subsubsection{Análisis intertextual}

Las conexiones intertextuales nos reenviarán a las películas previas sobre la Transición ${ }^{7}$ así como a sus antecedentes televisivos: los programas históricos emitidos anteriormente por TVE. La puesta en relieve de las continuidades y rupturas, y de las presencias y ausencias en las diferentes realizaciones, redundará en un mejor entendimiento de la serie.

\subsubsection{Análisis socio-cultural}

Teniendo en cuenta que un programa televisivo sobre el pasado reciente atañe obligadamente a los debates en curso acerca del periodo mentado, el contexto socio-cultural de referencia lo forman la crónica política y la historiografía. El cotejo de la trama y sus personajes con sus referentes reales (el Rey, Suárez, el PCE, etc.) posibilitará dilucidar qué relación guarda aquella con los hechos históricos y, en especial, con las primeras interpretaciones de la Transición elaboradas por historiadores liberales (Tusell, 1999) o socialdemócratas (Morodo, 1994).

\subsubsection{Resultados esperables:}

Al término de las operaciones consignadas dispondremos de abundantes datos del encuadre genérico de la serie, su esquema narrativo, los roles asignados a individualidades y colectivos de la sociedad española, el espectador modelo, su retórica veridictiva, su régimen de historicidad, el punto de vista de sus autores,

${ }^{7}$ La ciudad es nuestra (Calabuig y Cóndor, 1975) describe las luchas vecinales en los últimos años del franquismo; Operación Ogro (G. Pontecorvo, 1979) ficcionaliza el atentado a Carrero Blanco; Votad, votad malditos! (Soler, 1977), documental que recoge las opiniones de obreros de Barcelona ante los primeros comicios tras la muerte de Franco; Informe general (Portabella, 1976), documental creativo sobre el tránsito de la dictadura a un Estado de derecho; y el NO-DO, el noticiero creado durante el franquismo emitido en las salas de cine hasta 1981 
los condicionamientos institucionales, y sus relaciones con la historia académica y con otras obras audiovisuales del mismo tema.

Con esa plétora de información sabremos quiénes han sido realzados o excluidos de su relato, y si éste es una historia de vencedores, de vencidos, o una solución de compromiso, lo cual aclarará su significación política. Aparte de arrojar luz sobre la justicia de las críticas vertidas contra el programa por su retrato de aquel lapso histórico, el entendimiento alcanzado fortalecerá el conocimiento del papel jugado por la televisión española en la construcción de una historia común, y, en una perspectiva más amplia, del modus operandi de la representación mediática del pasado.

¿Qué no debemos esperar de esta batería analítica? Sin dudas, un panorama nítido de la recepción de la serie. Los datos producidos, incluido el retrato-robot del espectador modelo, servirán de parámetros comparativos para ulteriores estudios sobre las audiencias de La Transición.

La panoplia metodológica descrita excede las posibilidades de cualquier investigador solitario y reclama la labor de todo un equipo. Nada impide, por supuesto, que un estudioso aplique algunas de sus recetas a la estructura narrativa de la serie o a las circunstancias institucionales de su realización, a sabiendas del alcance parcial de sus hallazgos. No es la intención de este trabajo negar la validez de estudios semejantes sino afirmar la imposibilidad de exprimir la riqueza sociológica de un texto audiovisual centrándose en su mensaje o en sus condiciones de producción exclusivamente.

\section{BIBLIOGRAFÍA}

AIDEKA (2002): Estudio de investigación: Tratamiento informativo de TVE sobre la huelga general del $20 \mathrm{~J}$, disponible en: http://www.aideka.tv/images/stories/20J/ Huelgaweb.pdf

ALEGRE, S. (2000): "La Transición Española, un documental histórico", Filmhistoria, Vol. X, no. 3 pp.169-194.

ALONSO, L. E. (1988): "Entre el pragmatismo y el pansemilogismo. Notas sobre los usos (y abusos) del enfoque cualitativo en sociología", REIS n. ${ }^{\circ}$ 43, pp. 157-168.

BARTHES, R. (1974): ¿Por dónde empezar?, Barcelona, Tusquets.

BELL, E. \& GRAY, A. (2007): "History on television", European Journal of Cultural Studies, Vol. 10, n. ${ }^{\circ}$ 1, pp.113-133.

BORDWELL, D. Y THOMPSON, K. (1997): El cine clásico de Hollywood: estilo cinematográfico y modo de producción hasta 1960, Barcelona, Paidos.

BURGIN, V. (2004): Ensayos, Barcelona, Gustavo Gili.

BURKE, P. (2005): Visto y no visto. El uso de la imagen como documento histórico, Barcelona, Crítica.

BUSTAMANTE, E. (1999): La televisión económica, Barcelona, Gedisa.

CAGLE, C. (2016): Sociology on Film: Postwar Hollywood's Prestige Commodity, New Jersey, Rutgers University Press.

CANTOR, M. \& CANTOR, J. (1992): Prime-time television: content and control, London, Sage. 
CASETTI, F. (1994): Teorías del cine, Madrid, Cátedra.

CASTILHO COSTA, M. C. (2000): "The Brazilian telenovela: a case study", en D. FLEMING (comp.) Formations: 21 st Century Media Studies, Manchester, Manchester University Press, pp. 163-168.

COHN, W. (1976): "History for the Masses: Television Portrays the Past", Journal of Popular Culture, vol. 10, n. ${ }^{\circ}$ 2, pp. 280-289.

CHALVON-DEMERSAY, S. (1994): Mille scénarios: une enquête sur l'imagination en temps de crise, Paris, Métaillé.

CHAPMAN, J. (2011): "Television and history: The World at War", Historical Journal of Film, Radio and Television, Vol. 31, No 2, pp. 247-275.

CHALVON-DEMERSAY, S. (1996): "Une société élective. Scénarios pour un monde de relations choisies", Terrain, $\mathrm{n}^{\circ}$ 27, pp. 81-100.

CONDE MARTIN, L. (1996): "La televisión del PSOE: 1982-1996", Archivos de la Filmoteca, n. ${ }^{\circ}$ 23-24, pp. 140-159.

DE LAURETIS, T. (1989): Technologies of Gender: Essays on Theory, Film, and Fiction, London, Macmillan.

DENZIN, N. (1991): Images of postmodern society, Newbury Park (California), Sage.

ELSAESSER, T. (2000): Weimar Cinema and After: Germany's Historical Imaginary, London, Routledge.

ESCAMILLA, G.; CRADOCK, A. \& KAWACHI, I. (2000): "Women and smoking in Hollywood movies: a content analysis". American Journal of Public Health. Vol. 90, n. ${ }^{\circ} 3$, pp. 412-414. ESQUENAZI, J-P. (2012): "Les westerns de John Ford: Du libéralisme d'avant-guerre au conservatisme d'après-guerre», Mise au Point $\mathrm{n}^{\circ} 12$. http://map.revues.org/788

ESQUENAZI, J.P. (2004): Godard et la société française des années 60, Paris, Armand Colin Cinéma.

FRANCESCUTTI, P. (2004): La pantalla profética, Madrid, Cátedra.

FERRO, M. (1977): Cinéma et histoire, Paris, Denoël-Gonthier.

GALLEGO, F. (2008): El mito de la transición. La crisis del franquismo y los orígenes de la democracia (1973-1975). Barcelona, Crítica.

GITLIN, T. (1983): Inside Prime Time, New York, Pantheon Books.

GLASGOW UNIVERSITY MEDIA GROUP (1976): Bad News, London, Routledge \& K. Paul.

GONZÁLEZ REQUENA, J. (1985): “Film, discurso, texto. Hacia una teoría del texto artístico", Revista de Ciencias de la Información n. ${ }^{\circ}$ 1, pp. 15-40.

GUYNN, W. (2006): Writing History Film, New York, Routledge.

HALL, S. (2010): Sin garantías. Trayectorias y problemáticas en estudios culturales, Quito, Envión Editores.

HERF, J. (1990): El modernismo reaccionario. Tecnología, cultura y política en Weimar y el Tercer Reich, Buenos Aires, FCE.

HERNÁNDEZ CORCHETE, S. (2010): "El uso estratégico de la velocidad en el relato histórico realizado por la serie televisiva La Transición_, Comunicación y Hombre, no. 6, pp. 195-204.

HERNÁNDEZ CORCHETE, S. (2013): “Así se contó la Transición en TVE. De la legitimación de la democracia a la mitificación del proceso político”, en GUTIÉRREZ, Ruth (coord.), Poéticas de la persona. Creación, responsabilidad y vigencia en la Comunicación Pública y la Cultura, Comunicación Social, Salamanca, pp. 319-331. 
INCEER, M. (2007): “An Analysis of the Opening Credit Sequence inFilm”, CUREJ: College Undergraduate Research Electronic Journal, http://repository.upenn.edu/ curej/65.

JAMESON, F. (1995): La estética geopolítica. Cine y espacio en el sistema mundial. Barcelona, Paidos.

JARVIE, I. C. (1970): Movies and Society, New York, Basic Books.

JOWETT, G.; JARVIE, I.; \& FULLER, F. (1996): Children and the Movies: Media Influence and the Payne Fund Controversy, New York, Cambridge University Press.

KELLNER, D. (2009): Cinema Wars: Hollywood Film and Politics in the Bush-Cheney Era, New Jersey, Wiley-Blackwell.

KRACAUER, S. (1930): Die Angestellten/Los empleados (edición española de 2008, Gedisa, Barcelona).

KRACAUER, S. (1947): De Caligari a Hitler: una historia sociológica del cine alemán (edición española, Barcelona, Paidos, 1985).

MANCHEL, F. (1990): Film Study: An Analytical Bibliography, Vol 1, New Jersey, Fairleigh Dickinson University Press.

Mattelart, A. (2006): Diversidad cultural y mundialización, Barcelona, Paidós.

MORODO, R. (1994): La transición política, Madrid, Tecnos,

NICHOLS, B. (1991): La representación de la realidad. Cuestiones y conceptos sobre el documental, Barcelona, Paidós.

PALACIO, M. (2009): Historia de la televisión en España, Barcelona, Gedisa.

PAZ REBOLLO, M. A. y MONTERO DÍAZ, J. (2015) "Usos históricos de la historia en la transición española", Historia y Política, n. ${ }^{\circ} 33$, pp. 275-302.

ROSENSTONE, R. (1997): El pasado en imágenes, Barcelona, Ariel.

ROSITI, F. (1980): Historia y teoría de la cultura de masas, Barcelona, Gustavo Gili.

RUEDA LAFFOND, J. C., y CORONADO RUIZ, C. (2009): La mirada televisiva. Ficción y representación histórica en España, Madrid, Fragua.

SÁNCHEZ MECA, D. (2004): "El círculo hermenéutico y los límites de una filosofía de la lectura", Signa n. ${ }^{\circ} 13$, pp.139-160.

SCHATZ, T. (1981): Hollywood Genres: Formulas, Filmaking, and the Studio System, Austin, McGraw Hill.

SERRANO PASCUAL, A. y ZURDO, A.(2012): "Investigación social con materiales visuales", en M. Arroyo Menéndez e I. Sádaba Rodríguez (comps.), Metodología de la investigación social: técnicas innovadoras y sus aplicaciones, pp. 217-250.

SOBCHACK, V. (1979): "The grapes of wrath (1940): Thematic emphasis through visual style", American Quarterly, Vol. 31, n. ${ }^{\circ}$ 5, pp. 596-615.

SORLIN, P. (1977): Sociologie du cinema. Paris, Aubier Montaigne.

SPIGEL, L. (1991): "From domestic Space to Outer Space: The 1960s Fantastic familiy Sit Com", en C. PENLEY (comp.) Close encounters, Minneapolis, University of Minnesota Press, pp 205-223.

TEJEDOR, C. (2014): “Clase 1: raccord y decoupage", disponible en: https://rupuze. files.wordpress.com/2011/10/clase-1_raccord-dc3a9coupage-final-cut-hc3b6lgyeimc3a9s-uraim.pdf

TREACEY, M. (2016): Reframing the Past: History, Film and Television, New York, Routledge.

TUSELL, J. (1999): La transición española a la democracia, Madrid, Historia 16.

TURNER, G. (1988): Films as social practice, New York, Routledge. 
VEYRAT-MASSON, I. (2014): "Le documentaire à base d'archives au coeur de l'histoire à la télévision", E-dossiers de l'audiovisuel, disponible en: https://www. ina-expert.com/e-dossiers-de-1-audiovisuel/le-documentaire-a-base-d-archives-au-cur-de-1-histoire-a-la-television.html

WAYNE, Mike (2000): "Who wants to be a Millionaire? Contextual analysis and the endgame of public service televisión", en D. FLEMING (comp.) Formations: 21st Century Media Studies, Manchester, Manchester University Press, pp. 196-201.

WESTWELL, G. (2007): "Critical approaches to the history film-A field in search of a methodology", The Journal of Theory and Practice, Vol. 11, n. ${ }^{\circ}$ 4, pp. 577-588. WILlIAMS, R. (1974): Television: Technology and Cultural Form, New York, Schocken.

WOLFENSTEIN, M. \& LEITES, N. (1950): A psychological Study, Glencoe, The Free Press.

ZIZEK, S. (1994): ;Goza tu síntoma! Jacques Lacan dentro y fuera de Hollywood, Buenos Aires, Nueva Visión. 
